\title{
RAJA HAJI YAHYA IN THE HISTORY OF 20TH CENTURY MALAY LITERATURE ${ }^{1}$
}

\section{(Raja Haji Yahya dalam Sejarah Kesusasteraan Melayu Abad ke-20)}

\author{
Jelani Harun \\ jelani@usm.my
}

School of Humanities, Universiti Sains Malaysia, 11800 USM, Penang, Malaysia.

Tel.: +604-6532703

\begin{abstract}
Very little is known about the role of courtiers in the tradition of the Malay lipur lara (folklore) although the probability of them playing a role is hardly deniable. One such courtier is Raja Haji Yahya who lived in Chenderiang, Perak. Aside from producing works on the genealogy and history of the rulers of Perak, Raja Haji Yahya too was known to serve as penghulu (headman), pawang istana (royal medicine man), collector of folklore, and poet. In addition, he was well-acquainted with a prominent penglipur lara (folklorist) in Perak named Pawang Ana. This article aims to trace the life story of Raja Haji Yahya and discuss his contribution to the history of Malay literature in Perak. The study is based on several works of Raja Haji Yahya that have been found and also on information gathered from his next-of-kin who are still around today. The last part of the article puts forward a number of conclusions about the status of Raja Haji Yahya as a courtier who was blessed with deep insights into the literature and socio-cultural life of the Malays such that he deserves to be acknowledged as one of the leading lights in the history of Malay literature of 20th century Perak.
\end{abstract}

Keywords: Raja Haji Yahya, history of Malay literature, Pawang Ana, folklorist, Perak 


\begin{abstract}
Abstrak
Kewujudan "orang istana" dalam tradisi lipur lara Melayu masih belum banyak diketahui walaupun beberapa kemungkinan tentang peranan mereka sememangnya ada. Salah seorang "orang istana” yang dimaksudkan ialah Raja Haji Yahya yang tinggal di Chenderiang, Perak. Di samping menghasilkan penulisan tentang salasilah dan sejarah raja-raja Perak, Raja Haji Yahya juga pernah berkhidmat sebagai penghulu, pawang istana, pengumpul cerita rakyat, pengarang syair, dan mempunyai hubungan dengan tokoh penglipur lara di negeri Perak yang bernama Pawang Ana. Makalah ini bertujuan mengesan sejarah hidup Raja Haji Yahya dan membicarakan sumbangannya dalam sejarah kesusasteraan Melayu di negeri Perak. Kajian ini berasaskan beberapa contoh hasil karya Raja Haji Yahya yang telah ditemui dan juga maklumat yang diperoleh daripada waris keturunannya yang masih ada pada hari ini. Beberapa kesimpulan dibuat tentang kedudukan Raja Haji Yahya selaku "orang istana", yang mempunyai pelbagai kearifan tentang sastera dan sosiobudaya kehidupan masyarakat Melayu, sehingga beliau diangkat sebagai salah seorang tokoh penting dalam sejarah kesusasteraan Melayu di Negeri Perak pada abad ke-20 yang lalu.
\end{abstract}

Kata kunci: Raja Haji Yahya, sejarah kesusasteraan Melayu, Pawang Ana, Penglipur lara, Perak

\title{
INTRODUCTION
}

While rereading the early writings published in the Journal of the Straits Branch of the Royal Asiatic Society (JSBRAS), the writer came across several folk tales which had originated from Perak. Amongst them are the tales of Pelanduk Jenaka, Sang Kancil, Pa' Si Bago, Mat Jenin, Pa' Pandir, and Kherudin. In all cases, the stories were narrated by three headmen of Perak around the 1900s, viz. Mohamed Noordin bin Jaffar (headman of Kota Setia), Haji Mohamed Nasir bin Kanda Mat Sen (headman of Hutan Melintang) and Haji Mohamed Ali bin Haji Mohamed Perak (headman of Pulau Tiga). Who really were these headmen? It is indeed difficult to provide an answer to this question resulting thus in a lack of information on the identities of these folk tale narrators.

The tradition of Perak headmen transmitting folk tales orally is not something out of the ordinary as this very same tradition was also evident in the other Malay states. The headman, imam and medicine man made up part of the coterie who played an important role as narrators of Malay 
folk stories in the past. They were not professional story-tellers, rather they represented a small percentage of the common folks, and were looked up to as having knowledge which was to be shared with the local people. The state of Perak too had yet another headman who also had the ability to narrate and craft folk tales. The person referred to here is Raja Haji Yahya who was the headman of Chenderiang, Perak. However, unlike the other headmen, Raja Haji Yahya had family ties with the rulers of Perak.

From the perspective of court literature, the state of Perak had produced many courtiers who were men of letters who continue to be remembered until today. One such figure is Raja Chulan bin Raja Abdul Hamid who is much acclaimed as the author of Misa Melayu (1784). His vast store of knowledge, remarkable eloquence, and rapier wit had won him great honour and recognition amongst the people and the scholars of his time. His writings became reading materials for the nobility and the common folks, providing a guiding light in an effort to elucidate the history of the Perak sultanate which at the time, had not been clearly written.

Raja Chulan's extraordinary authorship in the 18 th century saw a repeat in Chenderiang around the early 20th century through the emergence of Raja Haji Yahya. The full name of the writer referred to is Raja Haji Yahya bin Raja Syed Muhammad Ali bin Raja Alang Syed Hussain. He worked as a headman in the state of Perak. Based on the works he authored, it is evident that Raja Haji Yahya was not merely a headman but also a historian, a writer and an amanuensis who copied down important narrated stories and folk tales in Perak during his time. He was also most likely a medicine man at the palace of the Perak sultan.

Raja Haji Yahya from Chenderiang is not the same as Raja Haji Yahya bin Raja Daud who lived in Belanja, Perak. The respected figure from Belanja, Raja Haji Yahya bin Raja Daud bin Tengku Besar Muda Abdul Rahman who originated from Siak, was one of the Orang Besar Lapan of Perak and held the title of Orang Kaya Kaya Imam Paduka Tuan. One of the the more important works of Raja Haji Yahya bin Raja Daud from Belanja is the Salasilah Raja-Raja yang di dalam Negeri Perak. Thus, there were two writers in the state of Perak at that time with the name of Raja Haji Yahya; one is Raja Haji Yahya bin Raja Daud who lived in Belanja and the other, Raja Haji Yahya bin Raja Muhammad Ali of Chenderiang. Both were important writers in the state of Perak, but they each came from a different background. ${ }^{2}$ 


\section{THE GENEALOGY OF RAJA HAJI YAHYA'S FAMILY}

Early information about Raja Haji Yahya can be found in A History of Perak jointly authored by Winstedt and Wilkinson (1934:166-71). It is said that Raja Haji Yahya had made a list of the names of genies believed to be "the Guardian Genies of the State" (Jin Kerajaan), including genies entrusted with guarding the Royal Regalia. There were 36 types of genies or jinns in all, each with its own name, responsibility and individual character. During any given palace ceremony, Sultan Muda and his assistant Raja Kecil Muda, will perform certain rituals to invoke the jinns. This is indicated by Winstedt and Wilkinson in the abstract below (1934:166):

A list of the guardian jinn (jin kerajaan) of Perak, or, to give them their other name, the genies of the royal drums and trumpets, whose indwelling spirits were fed and revived annually, was made many years ago by the late Raja Haji Yahya bin Raja Muhammad Ali of Chendriang, who on the distaff side was descended from Sultan Iskandar Zulkarnain and whose family had numbered a state pawang (Sultan Muda) among its members.

Based on the above annotation, we learned that Raja Haji Yahya was descended from the line of Sultan Iskandar Zulkarnain (Sultan Iskandar Dzulkarnain Shah, 1754-1764), and that he died in the year 1934. However, to this day, there is no definite information on his date of birth. Nevertheless, based on information elicited from his decendents, Raja Haji Yahya was believed to have been born some time around the middle of the 19th century and had grown up in Chenderiang, Perak. Chenderiang was a Malay village located roughly $20 \mathrm{~km}$ from the town, Tapah. This village was at one time a place where a group of nobles and some sayyid descendents in the state of Perak lived.

In March 2014, the writer had the opportunity of meeting one of the descendents of Raja Haji Yahya, that is, his nephew. The nephew meant here is Syed Nawawi bin Syed Mansur (aged 70) who currently lives in Shah Alam, Selangor. Syed Nawawi bin Syed Mansur too has a record of the genealogy of the family of Raja Haji Yahya which clearly shows family ties between the sayyids of Chenderiang and the sayyids of Terengganu. Upon studying this record, the writer found that the early part of the genealogy is similar to that of the family of Sayid Hussain al-Faradz as recorded by Winstedt and Wilkinson (1934:144). ${ }^{3}$

Based on the genealogical records in Syed Nawawi's keeping, the sayyid families living in Chenderiang were descended from Sayid Hussain 


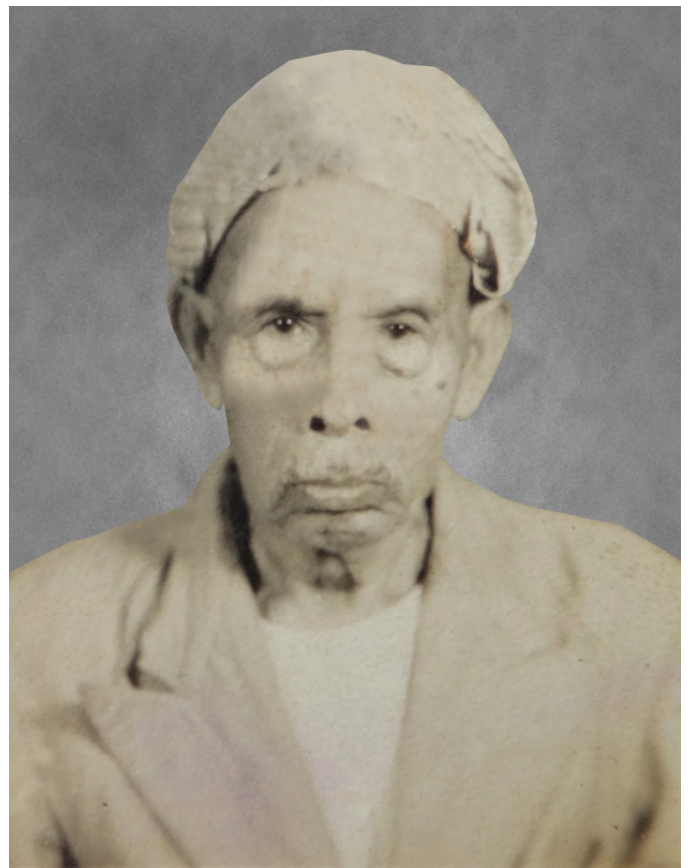

Figure 1 Syed Othman bin Syed Muhammad Ali, younger brother of Raja Haji Yahya.

Source: Tuan Syed Nawawi bin Syed Mansur

who originated from Hadramaut, Yemen. Sayid Hussain is believed to have arrived in Perak around the 17th century and had served at the palace of the Sultan of Perak. One of his descendents, Syed Hasan bin Syed Jalaluddin (Tok Tambak Pulau Pisang) later married Raja Shah Alam, the younger sister of Sultan Iskandar Dzulkarnain Shah (1754-1764). Their union was blessed with a son, Raja Sharif Bisnu (who took the title Sultan Muda Alauddin).

Raja Sharif Bisnu later married Raja Sabda Rasul, the daughter of Sultan Iskandar Dzulkarnain Shah (1754-1764). From this marriage was born a princess named Raja Hitam. The family ties between the Perak royal family and the family of the sayyids was further strengthened with the marriage of Raja Hitam to Syed Ahmad bin Syed Aqil bin Syed Yassin al-Faqih al-Yahya from Terengganu. The marriage of Raja Hitam to Syed Ahmad bin Syed Aqil resulted in the birth of Raja Syed Alang Hussain. Raja Syed Alang Hussain later begot a son Raja Syed Muhammad Ali, who was the father of Raja Haji Yahya. It is said that it was from this line of descent that a large family of rajas and sayyids had emerged in Chenderiang, Perak. ${ }^{4}$ 


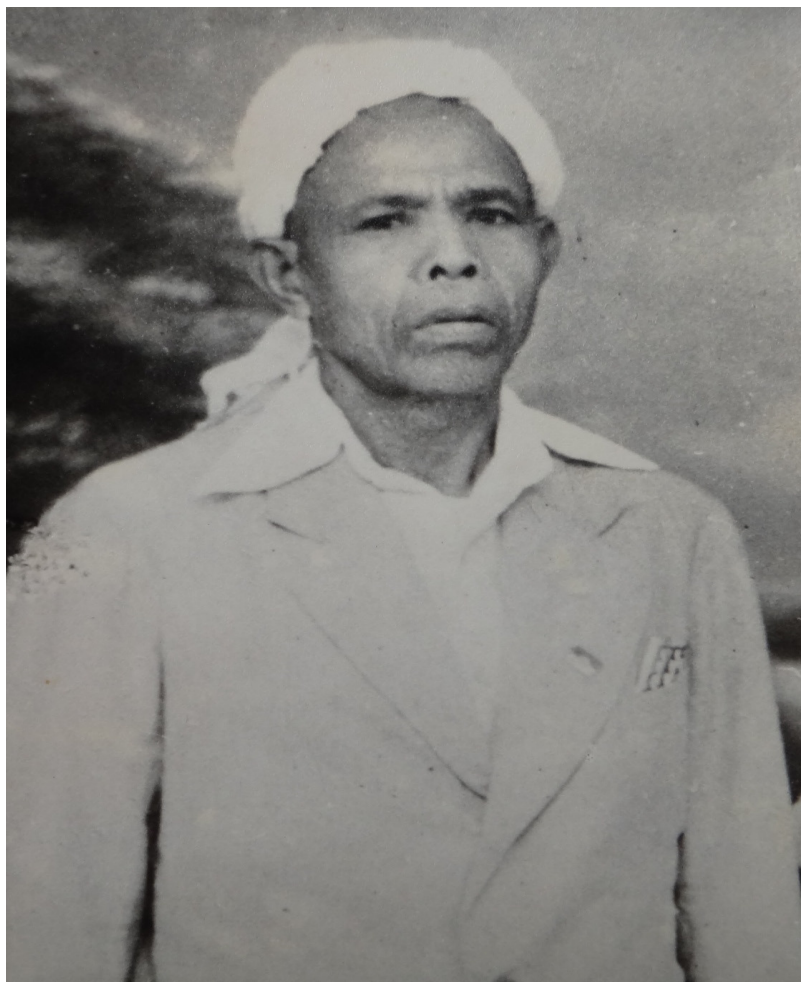

Figure 2 Syed Mansur bin Syed Muhammad Ali, younger brother of Raja Haji Yahya.

Source: Tuan Syed Nawawi bin Syed Mansur.

According to the information gathered from Syed Nawawi, Raja Haji Yahya was born Syed Yahya bin Syed Muhammad Ali. However, he later used the pseudonym, Raja Haji Yahya bin Raja Syed Muhammad Ali. Raja Haji Yahya had three younger brothers and a younger sister. His brothers were Syed Alwi, Syed Osman and Syed Mansur, while his sister was Sharifah Arfah. Each of his brothers had at one time or other worked as the headman of the sub-district of Teja, in the District of Kampar, Perak. In addition, they all served as religious teachers in their local communities in the state of Perak. Interestingly, all three maintained the title "Syed". Only Raja Haji Yahya used the title "Raja" on account of their line of descent through intermarriage with the noble family of Perak.

The information provided by Syed Nawawi bin Syed Mansur has in many ways helped to cast a light on several issues relating to the lifestory 
of Raja Haji Yahya about which society has been very much in the dark. Syed Nawawi also showed the writer two portraits, one of Syed Othman and another of Syed Mansur, the younger brothers of Raja Haji Yahya. It is unfortunate that Syed Nawawi does not have a single photograph of Raja Haji Yahya to be viewed by society. Other than that, efforts to establish the birth date of Raja Haji Yahya, as well as his life span have not met with any definite success.

Based on available data, the writer can only surmise that Raja Haji Yahya was perhaps born some time in the middle of the 19th century and died around the early 1930s. On the basis of this assumed lifespan, Raja Haji Yahya had spent much of his life working in the service of the state of Perak under the reigns of Sultan Idris Murshidul'azam Shah I (1887-1916), Sultan Abdul Jalil Karamatullah Shah (1916-1918) and Sultan Iskandar Shah Kadasullah (1918-1938). Up till today, the exact year Raja Haji Yahya went for pilgrimage to Mecca has still not been established but it is estimated that it was some time in the early 1900s.

Besides meeting Syed Nawawi in April 2014, the writer too met Raja Baharudin bin Raja Lope Zainuddin (aged 67) as well as his son, Raja Adley Paris Ishkandar bin Raja Baharudin (aged 36) who are related to Raja Kamaral Bahrain bin Raja Haji Yahya. The meeting was also attended by Syed Zamzuri bin Syed Mansur (aged 66) who is the nephew of Raja Haji Yahya. According to them, Raja Haji Yahya was married to Raja Long Aishah binti Raja Hassan (the daughter of Raja Bendahara Alang Iskandar Shah, Perak). From the marriage, Raja Haji Yahya was blessed with five children, Raja Kamaral Bahrain, Raja Sharifah Salamiah, Raja Sharifah Hamidah, Raja Syed Chik Abdul Majid and Raja Sharifah Hitam Hafifah. Among the five, only Raja Kamaral Bahrain followed in the footsteps of Raja Haji Yahya and became a writer. Raja Kamaral Bahrain (1901-1965) was born in Chenderiang and was married to Raja Yong Arba'ayah from the Perak royal household. From the marriage, he begot five children, Raja Shahruzzaman, Raja Shahrizan, Raja Haji Shahrustan, Raja Mariam and Raja Shahrin Nahrin. Out of the five grandchildren of Raja Haji Yahya, only Raja Shahrustan is still alive. He is now more than 90 years of age and lives in Subang, Selangor. According to the information gathered from Raja Adley Paris Ishkandar, Raja Kamaral Bahrain died in 1965 and was buried at the Royal Burial Ground in Bukit Chandan, Kuala Kangsar.

Among the children of Raja Haji Yahya, only Raja Kamaral Bahrain had written about the ceremonies at the court of Perak. This he did through the manuscript Susunan Yang Pertama Adat Lembaga Orang-orang Melayu 
JELANI HARUN

di dalam Negeri Perak Darul Ridzuan daripada Zaman Purbakala. The manuscript which was written in Jawi ${ }^{5}$ was printed in Taiping in 1935 with the title Susunan Yang Pertama Adat Lembaga Orang-Orang Melayu di dalam Negeri Perak Darul Ridzuan daripada Zaman Purbakala. One of the copies of the manuscript is now kept at Arkib Negara Malaysia (the National Archives of Malaysia), Kuala Lumpur (ANM No. ARA/28/ 2007/ 0052785). The manuscript comprises 60 pages and was written during the reign of Sultan Iskandar Shah (1918-1938). ${ }^{6}$

\section{Syed Hasan bin Syed Jalaluddin (Tok Tambak)}

Married

Raja Shah Alam, the younger sister of Sultan Iskandar Dzulkarnain Shah

$$
\text { \ु }
$$

Raja Sharif Bisnu (Sultan Muda Alauddin)

Married

Raja Sabda Rasul, the daughter of Sultan Iskandar Dzulkarnain Shah (1754-<smiles>[Te]=[W]</smiles>

Raja Hitam binti Raja Sharif Bisnu

Married

Syed Ahmad bin Syed Aqil bin Syed Yassin al-Faqih al-Yahya

(from Terengganu)

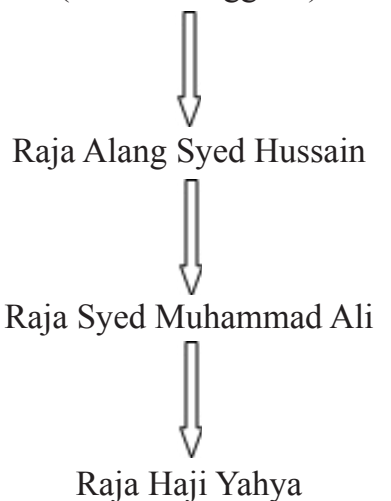

Figure 3 The genealogy of Raja Haji Yahya bin Raja Syed Muhammad Ali.

Source: Information modified by Tuan Syed Nawawi and YM Raja Adley. 
The name of the writer does not appear on the manuscript, but on its front page, the names of several dignitaries and members of the Perak royal household who were involved in its compilation are mentioned, namely, Raja Bendahara, Raja Kecil Sulung, Orang Kaya Besar Maharaja DiRaja, Raja Kamaral Bahrain and Raja Aman Shah. These dignitaries who were members of the royal household, were very familiar with life at the Perak court and given the authority to compile the customs and ceremonies of the royal court. Raja Kamaral Bahrain was at that time around 36 years old. A note on the front page of the manuscript Susunan Yang Pertama Adat Lembaga Orang-Orang Melayu di dalam Negeri Perak Darul Ridzuan daripada Zaman Purbakala reads:

Maka besarlah menerima kasih kita kepada Orang Kaya-kaya Setia Bijaya DiRaja Muhammad Nur al-Din (I.S.O) kerana ia mencadangkan susunan ini. Serta pula kepada ahli-ahli (committee) yang berusaha mengarangkan iaitu Yang Amat Mulia Tuanku Raja Bendahara, Yang Mulia Raja Kecil Sulung, Orang Kaya Besar Maharaja DiRaja, Yang Mulia Raja Qamar al-Bahrin dan Yang Mulia Raja Aman Shah, serta ahli-ahli tashihnya itu.

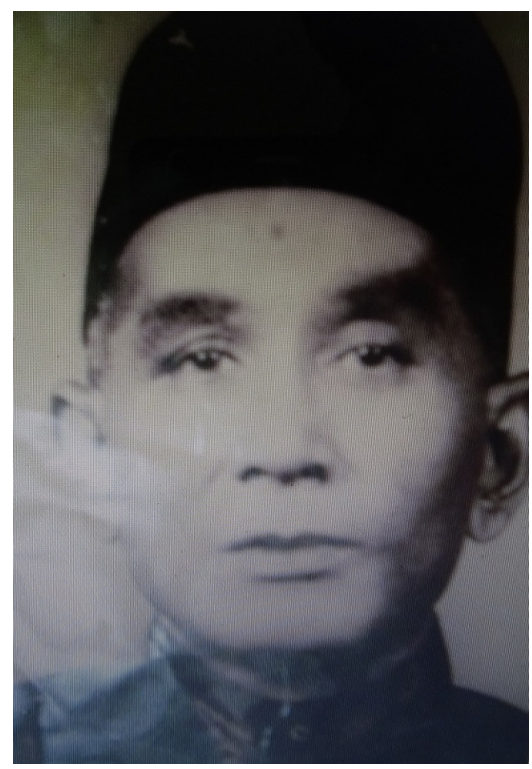

Figure 4 Raja Kamaral Bahrain bin Raja Haji Yahya.

Source: YM Raja Adley Paris Ishkandar. 
(We are geatly indebted to Orang Kaya-kaya Setia Bijaya DiRaja Muhammad Nur al-Din (I.S.O) for proposing the compilation of this manuscript. And to the members (of the committee) who have helped write it, namely Yang Amat Mulia Tuanku Raja Bendahara, Yang Mulia Raja Kecil Sulung, Orang Kaya Besar Maharaja DiRaja, Yang Mulia Raja Qamar al-Bahrin and Yang Mulia Raja Aman Shah, as well as those who authenticated it.)

According to information provided by Raja Adley Paris Ishkandar, there was talk among his family members of the possibility that the last place Raja Haji Yahya had taken up residence in was Kuala Dipang, Perak. As the story goes, Raja Haji Yahya's daughter, Raja Sharifah Hamidah, was married to Raja Hamzah bin Raja Ibrahim and had settled down in Kuala Dipang. In terms of location, Kuala Dipang is situated not very far from Chenderiang. It is believed that Raja Haji Yahya had died in Kuala Dipang in the year 1931. However, no one has been able to establish the exact location of his grave and this seems to demand further research.

\section{THE RELATIONSHIP BETWEEN RAJA HAJI YAHYA AND R.O. WINSTEDT}

It is reported that Raja Haji Yahya had enjoyed close relations with R.O. Winstedt. In fact, a large part of a book written by R.O. Winstedt was based on information elicited from Raja Haji Yahya, particularly sections concerning matters relating to the customs and ceremonies observed at the Perak court and in the Perak society. This may have a bearing on the position of R.O. Winstedt who had served in several districts in Perak, including Taiping, Kuala Kangsar, Krian, Gopeng, and Tapah around 1903-1907. Raja Haji Yahya, meanwhile, had the opportunity to communicate with Windstedt, and perhaps with other British officers as well, by virtue of his position as headman in the state of Perak at the time, during which the institution of headmanship was gradually being managed by the British colonizers.

In the year 1924, R.O. Winstedt was appointed Director of Education of the Federated Malay States and Straits Settlements, and was directly involved in efforts to publish reading materials for the Malay teachers at the time as part of his endeavour to establish the Sultan Idris Training College (SITC) in Tanjong Malim, in 1922. In order to accomplish the mission of compiling the reading materials, R.O. Winstedt had sought the assistance of Raja Haji Yahya who was then serving as headman of Chenderiang. For instance, in 
his book The Malay Magician, R.O. Winstedt (1982: 71) acknowledged Raja Haji Yahya's contribution to the project as shown below:

The account of the Perak ritual of feeding spirits immanent in the regalia was written for me by Raja Haji Yahya of Chendriang.

Apart from serving as the headman of Chenderiang, Raja Haji Yahya too was, at some time or other, headman of several other districts in the state of Perak. R.O. Winstedt, in writing the "Preface" to his Papers on Malay Subjects: Life and Customs (1909), expressed his appreciation of the contribution made by Raja Haji Yahya who was then the headman of Kota Setia. It is very probable that a lot of the information found in Winstedt's work was sourced from Raja Haji Yahya's repository of local knowledge. Thus, R.O. Winstedt noted in the "Preface" to his Papers on Malay Subjects: Life and Customs (1909):

I have to thank Abdulhamid, a Malay Writer in the Perak Secretariat, for much patient assistance; and, above all, Raja Haji Yahya, Penghulu now of Kota Setia, without whose profound repertory of lore and unflugging industry in writing it down this pamphlet would probably have been hardly more than a compilation from previous accounts, and whose information, however carefully tested by comparative investigation, I have never in one single instance found inaccurate or at fault.

Further information on the responsibilities of Raja Haji Yahya can be found in the "Senarai Penghulu di Mukim Batu Kurau" (List of the Headmen of Mukim Batu Kurau). The name of Raja Hj. Yahya b. Raja Syed Mohd. Ali is recorded on this list as the 9th headman of Kuala Kurau, who had served from $1905-1907 .{ }^{7}$ Based on this list, there is a possibility that Raja Haji Yahya was the headman of Batu Kurau during those two or three years. Meanwhile, in Abdur-Razzaq Lubis and Khoo Salma Nasution (2003:210), there is a register showing the names of those who qualified to act as assistants to the Shariah law magistrates in the whole of Perak in the year 1904. There are in all 82 names listed, including that of Raja Haji Yahya who was then the headman of Temoh. His duties as assistant magistrate of Chenderiang were delegated to Syed Abdul Hamid who was the assistant khadi.

Based on available data, it can be safely concluded that Raja Haji Yahya had served as headman in a number of districts in the state of Perak. His duties as headman at the end of the 19th and early 20th century involved a miscellany 
of communications with the palace and also the British administration. A headman is responsible for the sub-district under his control, in matters relating to law and order in the village, the administration of justice, religion, customs and ceremonies et cetera. According to Abdur-Razzaq Lubis and Khoo Salma Nasution (2003: 48), Raja Bilah who was the headman of Papan in 1882, was paid a monthly salary of 25 Ringgit. Perhaps, Raja Haji Yahya too was paid the same monthly salary at the time.

As headman, Raja Haji Yahya too had an in-depth knowledge of the history and traditional practices as well as the social customs of the Malays in Perak. His talent and ability as a writer were important assets at that time, especially for R.O. Winstedt who was then actively collecting and publishing reading materials in Malay. The acquaintance, or perhaps a more apt word, friendship, between R.O. Winstedt and Raja Haji Yahya, was recorded by the former in one of his books titled Start From Alif: Count From One: An Autobiographical Memoire (1969). The book contains jottings of the experiences of R.O. Winstedt while he was working in the Federated Malay States Civil Service around 1920-1940.

In the book, R.O. Winstedt (1969:116) recounts his experiences when he was in Tapah and Chenderiang, as well as his meeting with Raja Haji Yahya whom he nicknamed "Pot Lorrit". ${ }^{8}$ As R.O. Winstedt observes, not every Sayyid family living in Chenderiang enjoyed good fortunes or led a life of luxury; on the contrary, some families were poorly off and were in fact destitute. In this, R.O. Winstedt (1969:116) cited an analogy made by Raja Haji Yahya to protray the condition of life of the Sayyid families in Chenderiang then:

But as in the Hadramaut, so in Malaya the fortunes of Sayyids vary and several of the Chendriang ones were miserably poor. The "Pot Lorrit", Raja Haji Yahya, put their plight in a nut-shell, when he wrote that theirs was the fate of the golden coconut that may be planted only in princes' gardens: its fruits ripen and heaven knows the fate of the dry shells, destined to become some drinking vessels, some cups for rain-water, and some to fall downward, so that neither rain can assuage their thirst nor earth their emptiness. The oddest job any of the family had held was that of State Medicine-man ...

The citation from R.O. Winstedt above conjures an image of the living conditions of a group of Sayyids in Chenderiang around the 20th century; the fortunate ones lived comfortably while others lived in abject poverty. The writer is not certain about the life of Raja Haji Yahya while he was 
in Chenderiang; however, based on his position as headman, there is a possibility that he lived an ordinary life. The writer is also not certain about the source used by R.O. Winstedt when he referred to the writing of Raja Haji Yahya above; however, there is a great possibility that he had based it on the mansucript Salasilah Raja Perak Berhubungan dengan Sayid-Sayid (Sida-Sida) Chandaryang (The Genealogy of Perak Rulers in relation to the Sayyids (Sida-Sida) of Chandaryang). The manuscript was penned by Raja Haji Yahya of Chenderiang in the year 1908. At the beginning of the manuscript is an interesting comparison made by Raja Haji Yahya which is not dissimilar in meaning to the above abstract taken from R.O. Winstedt's book:

Sebermula, diceritakan orang yang empunya sahibul riwayat kepada zaman dahulukala, iaitu salasilah asal keturunan raja-raja waris negeri Perak ini dengan sayid-sayid yang ada di Chandaryang itu, laksana seperti ibarat nyiur gading, asalnya satu tandan jua, tetapi seumpama emas masing-masing mutunya kepada zaman sekarang.

In the beginning, it was narrated by the owner of the tale a long time ago, that the genealogy of the descendents of the rajas of Perak and the sayyids who lived in Chandaryang then, was like the yellow coconut (nyiur gading), originally all in one cluster, but like gold their quality is determined by the present.

In the broader context, the relationship between Raja Haji Yahya and R.O. Winstedt can be viewed from the angle of "modernization" in the writer's life. His acquaintance with the British officers opened his mind to the need for progress and the importance of knowledge. With the impetus provided by R.O. Winstedt, many folk tales and folk romances which before then were buried in the minds of the Perak Malays were collected and written down so that they would be of greater benefit to society. However, Raja Haji Yahya was Malay to the backbone. Until today, no writing of his has been found to disparage the Malays or glorify the British.

The British modern way of thinking seemed not to have affected the mind and authorship of Raja Haji Yahya at all. Although R.O. Winstedt spoke highly of Raja Haji Yahya's abilities, nowhere in his writings did Raja Haji Yahya reciprocate this gesture. Raja Haji Yahya's personality differed greatly from the personality of Abdullah bin Abdul Kadir Munshi who was a close associate of Stamford Raffles. This was probably because Abdullah 


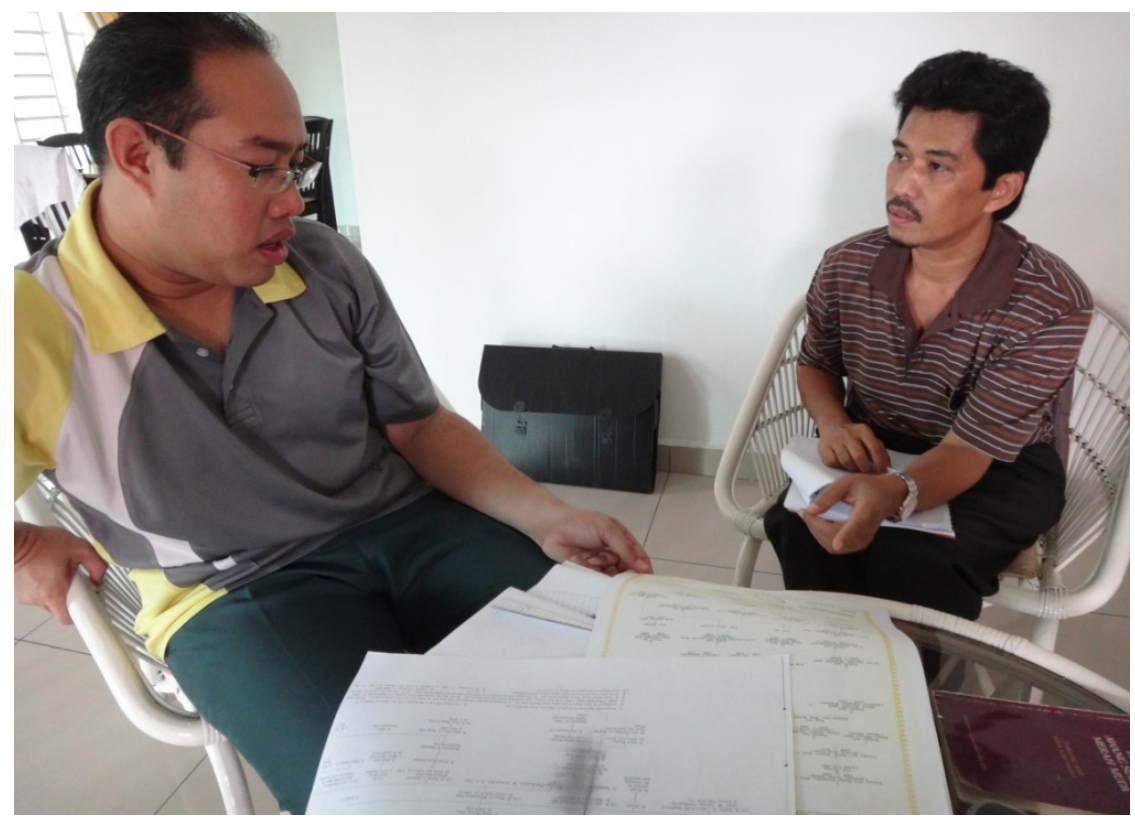

Figure 5 The writer discussing with HH Raja Adley Paris Ishkandar bin Raja Baharudin.

Source: Personal Collection, 2014.

Munshi was born and bred in a totally different environment, that is, in the cosmopolitan, rapidly developing city of Singapura. Raja Haji Yahya's character and personality perhaps bore a closer resemblance to that of Raja Ali Haji. The latter was a Malay poet and scholar from Riau who, although he was a friend of the Dutch officer, Von de Wall, remained steadfast in his effort to defend and ennoble the Malay culture and way of life.

\section{WORKS}

Data shows that Raja Haji Yahya was involved, be it directly or indirectly, in the writing of a number of manuscripts in the state of Perak. There are works in which he only served as the amanuensis, collator or compiler, and there are works in which he was the author himself. However, there is no evidence to show that it was part of his duty to act as the official writer at the Perak court. His works and activities in the field of writing were spurred 
by the genuine interest, talent and knowledge that he possessed. And, the motivation provided by R.O. Winstedt as well as other British officers was an added fillip. Perhaps he did receive some form of remuneration from the British government for the works he produced. Some of the works that may be associated with Raja Haji Yahya are summarized below.

\section{Writer and Modifier of Malay Folk Tales}

Raja Haji Yahya's name is widely known in the history of Malay letters as a writer or modifier of Malay legends such as Hikayat Raja Muda, Hikayat Awang Sulung Merah Muda, Hikayat Malim Deman, Hikayat Malim Dewa and Hikayat Anggun Che Tunggal. All these legends were originally narrated by a leading Malay folklorist from Chenderiang named Pawang Ana. ${ }^{9}$ According to R.O. Winstedt (1969:113), Pawang Ana was the headman ("a salaried headman") of Tapah. As such, his responsibilities as headman may have given him ample opportunities to communicate with Raja Haji Yahya who was then headman of Chenderiang, or perhaps it was the other way round.

Their awareness of the importance of documenting the folk tales narrated by Pawang Ana drove Winstedt dan Sturrock to request for the legends to be rewritten by Raja Haji Yahya bin Raja Syed Muhammad Ali. Unfortunately, when Raja Haji Yahya wrote the stories narrated by Pawang Ana, he did not offer any information about the latter, apart from what is contained in a brief note at the end of the stories which reads:

Demikianlah diceritakan oleh Pawang Ana yang empunya cerita serta dikarangkan oleh Raja Haji Yahya di Chenderiang di dalam negeri Perak Darul Ridzuan.

This is how the story goes as told by Pawang Ana, its custodian, and as written by Raja Haji Yahya from Chenderiang, Perak Darul Ridzuan.

(Hikayat Malim Deman, 1998:87)

Demikianlah diceritakan oleh Pawang Ana yang empunya cerita serta dikarangkan oleh Raja Haji Yahya di dalam Negeri Perak Darul Ridzwan.

This is how the story goes as told by Pawang Ana, its custodian, and as written by Raja Haji Yahya from Chenderiang, Perak Darul Ridzuan.

(Hikayat Raja Muda, 1999:128) 


\section{Collector and Author of Malay Comic Tales from Perak}

It was also discovered that Raja Haji Yahya had collected a host of comic tales from the state of Perak. Some of the tales were published by Penerbit Fajar Bakti in 1963 in Cerita Jenaka oleh Raja Haji Yahya. The tales featured in the book are Pak Kadok, Pak Pandir, Lebai Malang, Pak Belalang and Si Luncai. All the tales are popular comic tales that have been an integral part of Malay folk tradition since time immemorial. These comic tales were first published in 1908 in the "Malay literature series", under the titled Cherita Jenaka Ya-itu Pa Kadok, Pa Pandir, Lebai Malang, Pa Belalang, Si Lunchai, through the effort of R.O. Winstedt and Raja Haji Yahya.

The story of Pak Kadok and Pak Belalang contained social criticisms regarding the foolishness and greed of the Malay rulers while the other stories focus on the multifarious life of the ordinary citizen. Raja Haji Yahya and R.O. Winstedt make no mention of the real source of the stories. There is a great possibility that the stories were crafted by Raja Haji Yahya himself based on the oral tradition he had heard narrated over and over again within the Perak society. If one were to analyse it from this angle, it appears that Raja Haji Yahya had an insight into the qualities of a good and a bad ruler. At the same time, he created public awareness about the shortcomings and foibles to be avoided. Although all the tales were presented in a farcical manner, they however contain social comments that were trenchant, cynical and didactic.

In addition, Raja Haji Yahya collaborated with Daeng Abdulhamid to compile the tales of Hikayat Pelandok. The book is titled Hikayat Pelandok: Ia-itu Hikayat Sang Kanchil, Cherita dengan anak memerang, Hikayat Pelandok Jenaka and was published in 1915. There is a great possibility that the Daeng Abdulhamid meant here is the same Abdulhamid whom R.O. Winstedt referred to in his "Preface" to the Papers on Malay Subjects: Life and Customs (1909) as "a Malay Writer in the Perak Secretariat." Like all the other comic tales, the comic tales of the mousedeer (pelanduk) too contain innumerable social criticisms and moral lessons for man to learn from although they are presented through symbolic animal characters.

\section{The Writer of Cherita Pa' Musang}

Raja Haji Yahya also wrote a fable entitled Cherita Pa'Musang in which he incorporated advice for the reader. A copy of the entire story was published by R.O. Winstedt in the Journal of the Straits Branch of the Royal Asiatic 
Society, London, in 1908. The story is totally different from Hikayat Musang Berjanggut as it is about the effort of a civet cat which tries to conceive all kinds of ruses to make a meal of a hen and its two chicks. His relentless effort paid off and the civet cat finally succeeds in catching the chickens he desires. A note at the end of the story reads (Winstedt, 1908:90): "Di-karangkan oleh Penghulu Raja Haji Yahya bin Raja Muhammad Ali, di-mukim Chenderiang di-dalam negeri Perak." (Written by Headman Raja Haji Yahya bin Raja Muhammad Ali of Chenderiang, state of Perak)

\section{Writer of Salasilah Raja Perak Berhubungan dengan Sayid-Sayid Chandaryang}

A copy of Raja Haji Yahya's work entitled Salasilah Raja Perak Berhubungan dengan Sayid-Sayid Chandaryang ${ }^{10}$ (The Genealogy of the Rulers of Perak in Relation to the Sayyids of Chandaryang) is in the safekeeping of the Arkib Negara Malaysia (Malaysia National Archives), Kuala Lumpur. The work is kept at the Arkib Negara Malaysia, Kuala Lumpur, among a collection of works that used to be in the possession of Raja Kamarulzaman bin Raja Mansur (SP 9). It is 47 pages thick, $33.5 \mathrm{~cm}$ x $20.5 \mathrm{~cm}$ in dimension and typewritten in blue ink in the Rumi script (the Roman alphabet). Salasilah Raja Perak Berhubungan dengan Sayid-Sayid Chandaryang begins with the title page and a brief introduction by Raja Haji Yahya who outlines the relationship between the Perak rulers and the descendents of the Sayyids who lived in Chandaryang (Chenderiang). This he set out in metaphorical terms as seen below (1908:1):

Salasilah Raja Perak Berhubungan dengan Sayid-Sayid (Sida-Sida) Chandaryang

Sebermula, diceritakan orang yang empunya sahibul riwayat kepada zaman dahulukala, iaitu salasilah asal keturunan raja-raja waris negeri Perak ini dengan sayid-sayid yang ada di Chandaryang itu, laksana seperti ibarat nyiur gading, asalnya satu tandan jua, tetapi seumpama emas masing-masing mutunya kepada zaman sekarang.

(In the beginning, it was narrated by the owner of the tale a long time ago, that the genealogy of the descendents of the rajas of Perak and the sayyids who lived in Chandaryang then, was like the yellow coconut (nyiur gading), originally all in one cluster, but like gold their quality is determined by the present.) 
Meanwhile, in the colophon, the writer acknowledges the source text he had used to write the genealogy of the Perak rulers which he had obtained from four large sheets of paper. There is a possibility that the source used was written in the Jawi script and had been in the safekeeping of the family of Raja Haji Yahya or some other Perak royalty since the olden days. Besides that, the writer also disclosed the sources of the oral tales about the early history of the Perak rulers which he had heard from his parents. In addition, the writer dated the manuscript to 1908 and declared the author's name as Raja Haji Yahya bin Raja Mohamad Ali from Chenderiang, Perak. The colophon is as shown below (p. 47):

Demikian inilah keturunan seperti daftar di dalam list daftar yang hamba tuan permaklumkan empat keping kertas yang besar ke bawah kaus yang mulia dahulu, salasilah keturunan Sultan Perak ini yang akan jadi perhubungan dengan sayid-sayid (sida-sida) yang sebelah Chandaryang itu. Maka demikianlah ceritanya yang hamba tuan dapat. Maka hamba tuan menengar cerita ini daripada orang tua hamba tuan juga yang telah hamba tuan karangkan ini. Istimewa pula maka kepada fikiran hamba tuan silakanlah tuan banding pula jikalau mana yang silap dalam karangan ini, silalah betulkan. Maka demikianlah hamba tuan permaklumkan menceritakan orang yang punya cerita ini.

(Thus are the descendents as stated in the list of names which your humble servant had made known to your highness on four large sheets of paper, the genealogy of the Sultan of Perak in relation to the Sayyids (sida-sida) of Chandaryang. Such is the history which has come into your humble servant's possession. And your humble servant had heard this history from his father, a history which has now been written. Your humble servant would be most grateful if your highness could kindly correct any mistake that might have been made in the writing of this history. Hence your humble servant would like to disclose the owner of this history.

Wallah-hu-aalamu bis-sawab. (Allah knows best).

Khatam. (The end).

Termaktub kepada 27 haribulan 1908. (Dated the 27th, 1908)

Yang telah dikarangkan oleh hamba tuan yang hina, (Written by your humble servant),

Raja Haji Yahya bin Raja Mohamad Ali, Chandaryang, Perak. 


\section{Copyist of Ilmu Perubatan Melayu}

This manuscript which belonged to Raja Haji Yahya from Chenderiang, which he later gave to R.O Winstedt, is in the safekeeping of the SOAS Library, London. It has no specific title and is kept in a folio, MS 25027/2 Ilmu Perubatan Melayu. The manuscript was acquired by the SOAS Library from R.O. Winstedt. The section that is related to Ilmu Perubatan Melayu (The Art of Malay Charms) is written in black ink, in almost illegible large scrawls. The sheets of the manuscript measures $24 \mathrm{~cm} \times 18 \mathrm{~cm}$ each and are rather faded. On the back page is written the following:

A book of Malay charms formerly belonging to a Sultan Muda of Perak \& given to R.O. Winstedt by Raja Haji Yahya of Chendriang.

The above remark is evidence that points towards the fact that Raja Haji Yahya from Chenderiang had made the acquaintance of R.O. Winstedt some time in the distant past and had given the latter a manuscript on Malay charms. The manuscript abounds with all manner of tips on practices and prescriptions of Malay traditional medicine, including incantations, and the use of talismans and amulets. In some places, information provided for a given traditional cure will be accompanied by a rough diagram. Below is an abstract from the manuscript:

Ubat sembelit, sawan, azimat pengasih dan pembenci perempuan, kanakkanak tiada mahu menyusu, azimat kepada lelaki kalau hendak membuka hutan, pematah lidah orang, azimat menahan tuju orang, menahan syaitan.

(MS 25027/ p. 9)

Cure for constipation and seizures, love amulets, hate charms against women, cure for babies who refuse to suckle, talismans for men who are preparing to clear a jungle, charms for making someone dumbstruck, amulets to ward off evil spells, to ward off the devils.

(MS 25027/2, p. 9)

Bab ini azimat ubat orang kebal dan sakit, tangkal syaitan dan pelesit atau hantu atau jin, inilah rajahnya.

This chapter is about amulets for invulnerability, for curing illnesses, to ward off evil spirits and pelesit $^{11}$ or devils or jinns; see table. 
Bab ini tangkal syaitan jua, orang sakit demam, maka dibacakan pada limau tujuh kali senafas, maka diberikan diperlimaukan, inilah doanya.

This chapter is again about amulets to protect against evil spirits and to cure those with fever; take a lime and then read the incantation seven times in one breath, then apply the lime on the patient, here is the supplication.

(MS 25027/2, p. 28)

\section{Owner of Undang-Undang Sembilan Puluh Sembilan}

Based on the manuscript, Undang-Undang Sembilan Puluh Sembilan (The Ninety-Nine Laws) which is kept at the Malaysia National Archives, Kuala Lumpur, it is evident that the manuscript was written on lined paper. On the second page is stated: "Undang-undang yang dikurnia oleh Raja Haji Yahya." (Laws bestowed by Raja Haji Yahya). The name of the amanuensis who had copied the laws is stated in the colophon as Sayid Ja'far bin Sayid Yunus who had served as Dato' Penghulu Kuala Teja, Kinta, Perak. The manuscript was dated 12 October 1916. The manuscript contains the complete Undang-Undang Sembilan Puluh Sembilan, but there are some differences between it and the manuscript kept at SOAS, London. It is strongly believed that the manuscript kept at the Malaysia National Archives, Kuala Lumpur, had once belonged to Raja Haji Yahya as he was related to Sayid Ja'far bin Sayid Yunus.

\section{Knowledgeable about the Customs, Rituals and Way of Life of the Malays in Perak}

As mentioned earlier, when R.O. Winstedt was writing the Papers on Malay Subjects: Life and Customs (1909), Raja Haji Yahya who was then the headman of Kota Setia, proved an invaluable source of information for the British officer. In his book, R.O. Winstedt discusses matters relating to the court, the construction of houses, apparels, customs relating to marriage, decorations, food and so on, knowledge about which he (1909: 72) attributes to Raja Haji Yahya when he refers to his work as "An account written by Raja Haji Yahya". On one of the pages of the book written by R. O. Winstedt is a verse which is a "mantra" by Raja Haji Yahya: 
Nasinya beras Sungkai,

Ikannya lawang digulai dengan daun paku,

Pekasam ikan lokma,

Tempoyaknya tempoyak maja,

Airnya air Batang Padang,

Sirihnya sirih Chikus,

Kapurnya kapur Sungai Terap,

Siapa makannya tiada teringat ia pulang ke negerinya lagi.

The rice is from Sungkai

The fish is lawang cooked with paku ferns

The Pekasam ${ }^{12}$ is made of the lokma fish

The tempoyak $k^{13}$ is mixed with maja

The water is from Batang Padang

The betel leaves are from Chikus

The lime from Sungai Terap

Whosoever eats this, thinks no more of returning to his homeland.

\section{Writer of a Symbolic Syair}

Raja Haji Yahya is known to have written a syair which is symbolic in nature. The entire syair was featured in JMBRAS (12), Part II, published in 1934 (pp. 169-70. The syair has no specific title but is vaguely referred to as: "A Shaer by the late Raja Haji Yahya bin Raja Muhammad Ali". The writer is not very certain whether or not the syair has some implicit meaning or is merely Raja Haji Yahya's outpouring of emotion, being a poet who took a critical view of the social problems faced by the society then. Interestingly, the syair employs poetic devices such as parallelism and analogy to stimulate the reader into pondering its written and implied meanings. It was the norm amongst writers of olden times to present their criticisms through symbolism so that they may continue to maintain their good name and preserve public order, as they offer advice to society with judiciousness and wisdom. Below is an abstract from the syair of Raja Haji Yahya:

Sangat-lah hairan fakir memandang, Gunong yang tinggi menjadi padang,

Sa-lama tikus pandai bergendang,

Katak melompat menchabut pedang. 
Di-dalam hati sangat-lah pusang,

Melihat pengkalan di-tutup pasang.

Sa-lama birah menjadi pisang,

Biawak pun sudah menjadi musang.

Kepada fikiran sesak dan walang,

Memandang pipit menggonggong helang.

Sa-lama harimau tiada berbelang,

Di-atas tengkok-nya kambing berjulang.

Ajaib temenong hairan tefekor,

Melihat puyoh panjang-nya ekor,

Chenderawaseh menjadi pikor,

Sa-buah lautan habis terbongkor.

Kehendak Allah susah terbahagi,

Lembing yang tajam menjadi seligi,

Sa-lama kuching tiada bergigi,

Di-hadapan-nya tikus pulang pergi.

The pauper watches in amazement

As the lofty mountain is leveled to a field

For as long as the mouse beats the drums

The frogs will jump with swords drawn.

The heart is extremely perturbed

Seeing the pier submerged by the tide

For as long as the yam is taken for bananas

Monitor lizards will be taken for civets.

To a mind troubled and depressed

Seeing a sparrow devour an eagle

When the tiger loses its stripes

On its back a goat stands upright.

Miracles confound surprises prompt meditation

Seeing a quail with an overlong tail

The bird-of-paradise becomes a partridge

A whole ocean roils and tumbles.

Allah's commands are to be obeyed ...

A sharp spear becomes a pike 
For as long as the cat has no bite

Before it the mouse will strut.

\section{Raja Haji Yahya and Beting Beras Basah}

According to Winstedt and Wilkinson (1934), Raja Haji Yahya had, in his possession, a list of the names of the jinns that watch over the administration of Perak, including the jinn named "Sultan Pahlawan Chakera Dunia" (20th jinn) which sat astride a magic jewel. "Sultan Pahlawan Chakera Dunia" is purportedly the guardian jinn of Beting Beras Basah which is situated in Bagan Datoh, Perak. Raja Haji Yahya describes part of the jinn's character in mantra form as shown below (Winstedt and Wilkinson, 1934:168):

Raja bukan sa-barang raja,

Dewa bukan sa-barang dewa,

Raja di Beting Beras Basah,

Alam di-padang seri mutia.

No ordinary raja is it

Nor an ordinary deity

but the Raja of Beting Beras Basah

The universe a field of glowy pearls.

Until today, Beting Beras Basah is believed to be the place where the ship of Sultan Muzaffar Shah (the son of Sultan Mahmud Shah, the sultan of Malacca who died in Kampar in 1530) had run aground before his majesty succeeded in ascending the throne as the first Sultan of Perak in Tanah Abang (Teluk Bakong, Lambor Kanan). The incident is said to have taken place in 1528, and until today, Beting Beras Basah continues to be one of the locations visited by the sultans upon their accession to the throne of Perak. To the writer's knowledge, Raja Haji Yahya had never served as Pawang DiRaja (Royal Medicine man) at the court of the Sultan of Perak, which carries the title Sultan Muda or Raja Kecil Muda. Nevertheless, Raja Haji Yahya's involvement in matters relating to traditional medicine and divination at the court, seem to suggest that he was knowledgeable about such practices that prevailed at the Perak court at that time.

According to M.A. Fawzi Basri in his book Cempaka Sari: Sejarah Kesultanan Negeri Perak (1986:15), the legend about Beting Beras Basah is based on stories from the oral lore narrated by Paduka Seri Sultan Idris 
al-Mutawakkil Allallahi Shah, the 33rd Sultan of Perak, who ruled from 1963-1984. Paduka Seri Sultan Idris himself had visited Beting Beras Basah during his coronation. This tradition was perpetuated by Paduka Seri Sultan Azlan when he ascended the throne of Perak in 1984.

Notwithstanding the issues surrounding Beting Beras Basah, the town is situated close to Kuala Sungai Perak, and is located in the district of Bagan Datoh. The connection between the coronation traditions of the Perak sultans and Beting Beras Basah has in many ways helped attract public attention to Bagan Datoh. Today, a concrete jetty has been constructed to provide easy access to the area known as Beting Beras Basah which is surrounded by a mangrove swamp. An important place such as this deserves greater attention from the relevant authorities in Bagan Datoh. At the very least, it should be developed into an eco-friendly tourism attraction, without undermining the natural beauty of a place significant in the custom and tradition of the rulers of Perak. The "mantra" written by Raja Haji Yahya signifies the mystic quality of Beting Beras Basah.

\section{THE RELATIONSHIP BETWEEN RAJA HAJI YAHYA AND PAWANG ANA}

Pawang Ana was well-known as a story teller in Perak. However, his real identity has yet to be ascertained. It was the normal practice for the tale teller not to state his name or identity in the stories he narrated. His designation, "Pawang", suggests that he was a medicine man, a shaman, or a healer in the kampong. ${ }^{14}$ As Pawang Ana's identity has yet to be determined, the identity of his father and family too may continue to remain unknown to today's society.

An important piece of information about Pawang Ana is recorded by R.O. Winstedt in his book Start From Alif: Count From One: An Autobiographical Memoire (1969: 113). In the book, R.O. Winstedt gives the impression that Pawang Ana was someone who was illiterate and "a man of strong personality and physique like so many of the old type of headman. ${ }^{15}$ " Pawang Ana too was said to be "a Bugis Malay who had recovered the body of Mr. Birch, the first Resident of Perak, from the river after his murder." This piece of information from R.O. Winstedt affords us several notions about Pawang Ana who was at the time a headman in Tapah, and perhaps too, was very knowledgeable about traditional medicine and shamanism as to be able to trace the body of J.W.W. Birch who was assassinated in Sungai Perak in 
1874. However, Zabidin Ismail (2010) in his study gives a new slant to the origins of Pawang Ana who lived in Gopeng, Perak, and is said to be of Rawa descent (from Rao, Sumatra).

According to R.O. Winstedt again (1969:114), he had succeeded in collecting five Malay folk tales, each "seven hundred pages" thick from Pawang Ana. Although he did not state it clearly in the book, but in the effort of compiling the stories he was assisted by Raja Haji Yahya whose job was to copy down the tales. Among the folk tales narrated by Pawang Ana and copied or rewritten by Raja Haji Yahya are Hikayat Awang Sulung Merah Muda, Hikayat Malim Deman and Hikayat Raja Muda. The tales in this first collection revolve around life at the Perak royal court and adhere to the stereotype structure of other Malay folk tales. The plot line proceeds along a conventional sequence of events from beginning to end. Each of the tales has a happy ending with the hero marrying the heroine and consequently returning once again to the palace to become the ruler of a bigger country.

The second collection of stories from Pawang Ana consists of a number of tales that contain new elements, specifically those relating to the arrival of the Portuguese or rather, the colonization of part of the Malay Peninsula by a Western power. In this second collection, Pawang Ana's narrative pattern still manifests a number of the basic characteristics of the plot of Malay folk tales but with added embellishments and modifications to the theme, characterization and the objective of the story. In his tales, Pawang Ana not only relates the stories but also evinces his protest against the arrival of colonial power, the Portuguese, in Malacca around 1511. The tales referred to here are Hikayat Anggun Che Tunggal and Hikayat Malim Dewa. In both legends, the enemy of the hero is no longer a villainous raja, jinn, giant or an evil spirit, instead he is the king of Portugal.

Until today, the writer is still uncertain about the actual working method employed by R.O. Winstedt and Raja Haji Yahya when they were copying down or rewriting the tales narrated by Pawang Ana. Were the stories recorded (perhaps R.O. Winstedt had a tape recorder at that time) or were they written down then and there by Raja Haji Yahya? Did Raja Haji Yahya copy down verbatim what was narrated to him, or did he amend and edit them later? These questions are still waiting to be answered and prompt further research. Regardless of the situation, the writer is quite convinced that Raja Haji Yahya had carried out his task according to the normal practice of the amanuenses of old who copied down what was narrated to them and at the same time embroider, rewrite and edit the tales according to their creativity. 


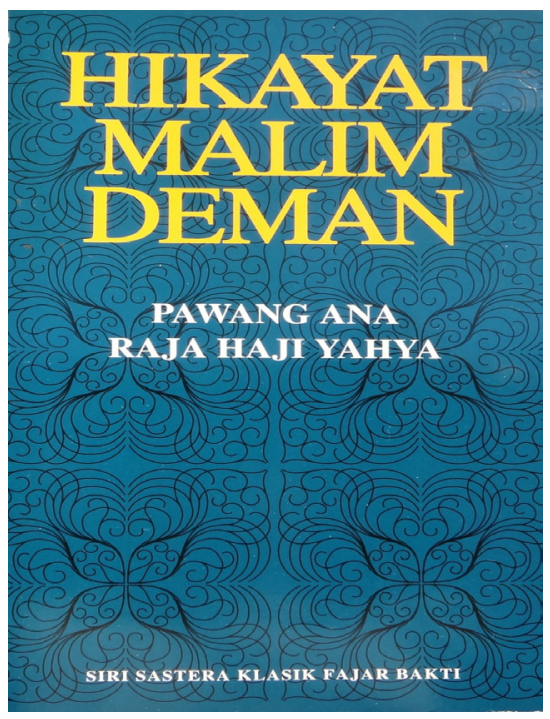

Figure 6 Hikayat Malim Deman.

In other words, the published folk tales narrated by Pawang Ana that we have today are tales that had undergone some form of "intervention" from Raja Haji Yahya as the author. Thus, it is most appropriate that these publications should bear the names of both Pawang Ana and Raja Haji Yahya.

According to his life story, Pawang Ana is said to have a son-in-law, Mir Hassan from Kampar, Perak, who had the same interest and skill as he. After Pawang Ana, Mir Hassan emerged as another important Malay folklorist in Perak. At least three stories were acquired by W.E. Maxwell from Mir Hassan, that is, Seri Rama dated 1886, Raja Donan dated 1886 and Raja Ambong dated 1886. The original manuscripts of all three tales are kept at the Royal Asiatic Society, London (MS Maxwell 7). As usual, not much at all is known about Mir Hassan.

Among the three legends, Hikayat Raja Donan presents a theme almost similar to that of Hikayat Anggun Che Tunggal and Hikayat Malim Dewa which were narrated by Pawang Ana. The legend is about a princess who was forced to flee her country by ship with her brother, Chamar Laut, as she did not wish to marry Raja Petukal (the king of Portugal). During their voyage, a clash ensued between Chamar Laut and Raja Donan, resulting in the former being killed. Raja Donan who took pity on the princess for the misfortune that had befallen her, went to seek out Raja Petukal whose ship 
was at that time berthed somewhere in negeri Lubok Goa Batu. While Raja Donan was in negeri Lubok Goa Batu, Raja Petukal had ordered his men to collect a sea levy from him but did not succeed. This resulted in a battle between Raja Petukal's forces and that of Raja Donan's which led to Raja Petukal's death (see Hikayat Raja Donan, in. Maxwell, 1886:269):

Raja Donan sudah tajalli di hadapan Raja Petukal itu lalu ditangkap pula Raja Petukal itu serta dilambung-lambungkan tiga kali sampai ke awan biru dan dipusing-pusing pula tiga kali. Maka menggerutup segala sendi tulang Raja Petukal itu, lalu dibalingkan pula, singgah di kayu, kayu patah, jika singgah di gunung, gunung runtuh. Maka Raja Petukal itu pun jatuh ke laut yang makan orang iaitu Pusat Tasik Pauh Janggi, lalu Raja Petukal itu pun mati.

Raja Donan materialized before Raja Petukal and Raja Petukal was captured and thrown high up into the heavens three times and was spun around three times. Such it was that all the joints of Raja Petukal crackled; then he was again flung far into the air, landed on a branch, the branch broke; had he landed on a mountain, the mountain would have come crashing down. Whereupon Raja Petukal fell into a man-eating sea, that is, Pusat Tasik Pauh Janggi, and Raja Petukal was killed.

In several of the above works, the attitude of the Malay story tellers towards the colonization of a Malay state by the Portuguese is clearly seen. To them, there would be retribution for the cruelties perpetrated against them, and that the rulers of Portugal who were involved had been killed and their country destroyed by the heroes of the Malay Archipelago. Pawang Ana and Mir Hassan were more than story tellers as they also played a role in making subtle criticisms or biting innuendoes against the brutality of the colonizers which the locals had to endure with tenacity. This at once debunks the long-held contention that Malay folklore is only filled with fabulous tales and fantasies.

There is a big possibility too that some of the folk tales narrated by Pawang Ana were the products of Raja Haji Yahya's creative imagination, and were thus tales which Raja Haji Yahya himself had crafted. As a writer of stories, Raja Haji Yahya had a creative mind and had thus embellished the tales narrated by Pawang Ana. ${ }^{16}$ This gives us an insight into the position taken by Raja Haji Yahya which happened to be in line with Pawang Ana's, as regards his opposition to the arrival of the colonizers on Malay soil. May those who read or listen to the narration of these legends grasp the written 
and implied message the narrator and writer wish to convey regarding love for one's country.

\section{PERAK'S LITERARY LUMINARIES}

Efforts to push these luminaries of the past back into the literary limelight of today's society will open up opportunities for discussions on the contributions made by these acclaimed figures. Their lofty minds act not only as torchbearers in the life of the society of yesteryears but will continue to traverse the boundaries of time, lighting up our now borderless civilization. These pujangga Melayu (Malay literary luminaries) were intellectuals and thinkers of their time. They were geniuses, scholars and experts in their own fields. A number of them had produced a variety of work which are the pride of the Malay world until today. The strength of their works lies not only in the content and advice offered for the development of humankind, but also in the time-hallowed art of Malay letters and authorship they embody, justifying thus the elevation of their creators to the status of Malay literary luminaries. Hence, famous names such as Tun Seri Lanang, Hamzah Fansuri, Raja Chulan and Raja Ali Haji have been exalted to the status of literary greats of the Malay World.

Malay literary luminaries occupied centre stage in the society of their time, were consultants at the royal courts, and served and dedicated their time to their king and country. In the society they lived, they acted as gurus in the various fields, were leaders, littérateurs, men of letters, custom and ceremony consultants, story tellers, as well as poets, and experts on proverbs, analogies, traditional tips and others. Broadly speaking, Malay literary luminaries were intellectuals from whom society sought advice, opinion, comments and criticism. The depth of their knowledge, and their linguistic and intellectual adroitness had qualified them as littérateurs who deserved to be honoured and acknowledged by society, and to be held in high esteem by the scholars of their time. Their writings became reading materials at the courts and in their communities, and illumined every facet of life. This continued through the inexorable passage of time until there emerged a group of Malay literary luminaries who were by no means small in number, who lived and made a name for themselves in every corner of the Malay World.

The writer is of the opinion that Raja Haji Yahya had played his part in ennobling the language, literature and way of life of the Malays in the state of Perak in the early 20th century. If Pawang Ana is recognized as a 
legendary folklorist of Perak, Raja Haji Yahya is no less distinguished as a literary giant in the state. He was also a Malay literary luminary who had inherited knowledge of Malay traditions in both spoken and written forms. Although he was not in the same league as Tun Seri Lanang, Raja Ali Haji or Raja Chulan, nevertheless he had striven to keep alive the legacy of the great Malay writers of the past who were preservers of a rich cultural heritage.

Mohd. Taib Osman (1989) was among the earliest scholars of Malay studies to use Malay folklore as research material when he wrote his $\mathrm{PhD}$ thesis at Indiana University, Bloomington, in 1967. In his research, he drew a clear distinction between tradition and religious practice, and noted how early traditional Malay medicine was closely related to the institution of religion. The rituals observed by the healers, shamans, or medicine men, were usually followed by the recitation of supplications for well-being by the imam, pious men and so on. Nevertheless, the distinction made between the role of the healer and that of the imam may not necessarily hold true anymore

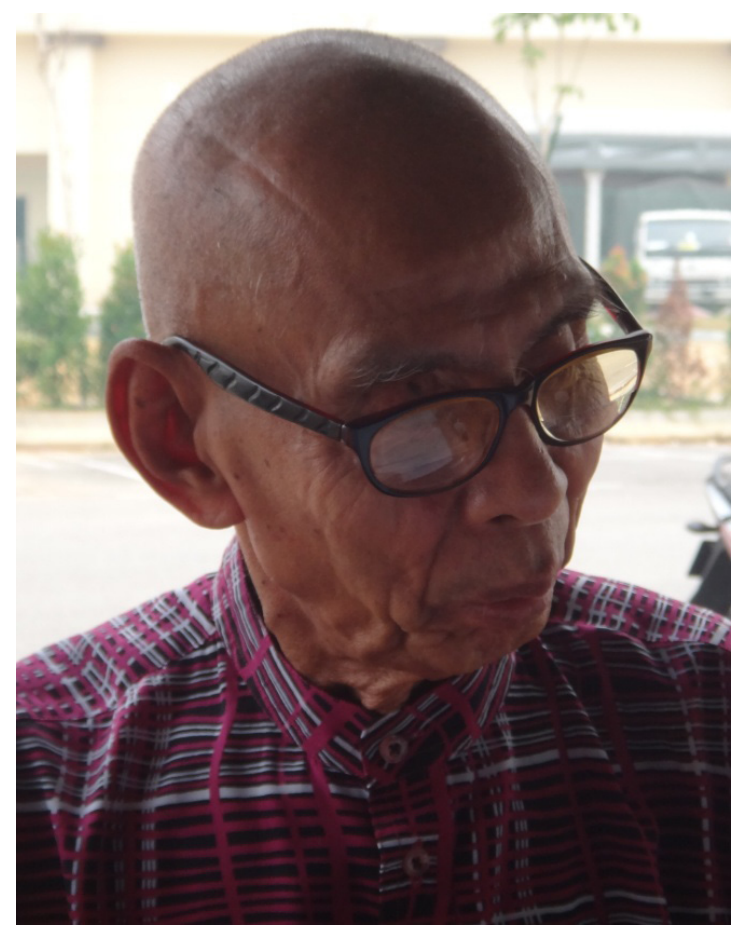

Figure 7 Tuan Syed Nawawi bin Syed Mansur, nephew of Raja Haji. 
for literary luminaries such as Raja Haji Yahya. He had mastered various aspects of traditional Malay life which were considered important during that period, be it in his role as a leader, historian, story teller, medicine man, religious elder et cetera. He was able to preside over traditional ceremonies at the royal court as well as in the kampongs, recite incantations (jampi) and mantras, and at the same time, lead thanksgiving prayers. Although "royal" blood and the blood of the "sayids" coursed through him, he was always genial when interacting with the common people.

\section{CONCLUSION}

To write a longer and more complete life story of Raja Haji Yahya requires greater effort and a longer time. More written sources need to be researched and much more data has to be collected from and discussed with his next-of- . Besides that, the reading of these sources has to be complemented with the carrying out of various studies of manuscripts kept within the country and abroad, especially those related to Raja Haji Yahya. No less important too is the assortment of notes taken down by R.O. Winstedt and other officers of the British Empire who had communicated directly with Raja Haji Yahya. All these materials have to be checked through to get more comprehensive information on the life of Raja Haji Yahya.

As a more exhaustive study has yet to reach the drawing board, this article sets forth a number of discussion points which could be presented to society at large as well as to researchers. From the study conducted, it is evident that Raja Haji Yahya was one of Perak's distinguished writers who had made a key contribution in the history of Malay letters. He not only lived in the tradition of court literature but was also closely acquainted with the oral tradition of the Malays of Perak. His name is associated with both the court and folk literature of Perak. This is what makes Raja Haji Yahya unique and extraordinary, a royal man of letters who did not sever ties with oral tradition which is the national heritage of his people.

The period during which Raja Haji Yahya made his greatest contribution must surely be the time when he was copying down or rewriting the folk tales narrated by Pawang Ana. In the old days, the job of a writer was not merely to write down verbatim what was narrated to him; often times he would embroider the stories he had heard using his own creativity. As such, there is a great possibility that all the legends narrated by Pawang Ana, which are available today, are also partly the handiwork of Raja Haji Yahya. On 
account of this, all of Pawang Ana's narrations which have been published also bear the name of Raja Haji Yahya as writer. Until today, the legends narrated by Pawang Ana and written down by Raja Haji Yahya are still used as teaching materials in classical literature classes in schools and institutions of higher learning, in Malaysia as well as abroad.

For a writer of note, the life of Raja Haji Yahya is still very much shrouded in mystery which has yet to be uncovered. The details of his date of birth as well as the date on which he died remain unclear. So are also the details regarding the place where he was born and where he grew up; whether it was in Chenderiang or some other place. As a matter of fact, until today, the writer has failed to trace the site on which his house had stood or the graveyard where he was laid to rest. All these create opportunities for more in-depth investigations by scholars and researchers in the future. All his next-of-kin who were interviewed stated that Raja Haji Yahya did not leave behind a fortune. What he left behind for his family members and kinsfolk to remember him by were his priceless works.

The time has come for Raja Haji Yahya bin Raja Syed Muhammad Ali to be recognized as the Malay literary luminary of Perak, of the early 20th century. Immediate effort must be undertaken, especially by the Government of Perak Darul Ridzuan and institutions responsible for preserving and conserving the history and local heritage of the state, as well as literary and cultural activists, writers associations, his next-of-kin and the people of Perak as a whole. If in 1969, R.O. Winstedt had given Raja Haji Yahya the title "Pot Lorrit" (Poet Laureate), it is surely time that the Malays of Malaysia today recognize him as and accord him the status of 20th century Literary Laureate of Perak, or honour him with other loftier accolades.

\section{NOTES}

1. This article is part of the findings of a research grant, Alam Pentadbiran Melayu Merentas Zaman: Citra Politik dan Adat Istiadat Pemerintahan Kerajaan Melayu, USM Pulau Pinang, 15 August 2011-14 August 2014.

2. See further notes on Raja Haji Yahya bin Raja Daud in Umpama Sebuah Bahtera by Jelani Harun (2011).

3. My heartfelt thanks go to the next-of-kin of Raja Haji Yahya bin Raja Syed Muhammad Ali, in particular Syed Nawawi bin Syed Mansur (Shah Alam), Syed Zamzuri bin Syed Mansur (Kulim), HH Raja Baharudin bin Raja Lope Zainuddin (Kulim) and YM Raja Adley Paris Ishkandar bin Raja Baharudin (Bukit Tambun), who had provided a 
lot of assistance and information on Raja Haji Yahya. Many thanks too are due to Dr. Mohamad Luthfi Abdul Rahman and Ms Noridah Kamari (USM) for their invaluable assistance.

4. Some of the descendents of sayyids and members of the Perak royalty still live in Chenderiang till this day. In the early part of the 19th century, Chenderiang was one of the tin-mining districts of Perak. In present-day Chenderiang, there is a picnic area by a waterfall, "Lata Kinjang", which attracts many visitors.

5. A modified Arabic alphabet used for writing the Malay language

6. The reference at the National Archives of Malaysia uses the title Adat Lembaga OrangOrang Melayu di dalam Negeri Perak Darul Ridzuan daripada Zaman Purbakala (ANM No. ARA/28/). There is a note on the cover of the manuscript which states that the manuscript was given as a gift by Temenggong Paduka Raja Dato' Wan Omar bin Dato' Seri Wan Hamaruddin, of 22, Jalan Taiping, Kuala Kangsar, Perak, on 3.5.1984.

7. "Senarai Penghulu di Mukim Batu Kurau" was sourced from: http://ms.wikipedia.org/ wiki/Batu Kurau, surfed on 5 Mac 2010.

8. Probably it is "Poet Laureate", a title which has been used in England since the 16th century, and accorded specifically to illustrious poets of a given period.

9. In the past, a healer (shaman or medicine man) who was good at narrating a tale was regarded as a virtuoso, literary luminary or folklorist.

10. 'The actual title (typewritten) is Salasilah Raja Perak Berhubungan dengan Sida-Sida Chandaryang. However, in the manuscript, the word "Sida-Sida" has been struck out with a black pen and overwritten with the word "Sayid-Sayid". It cannot be ascertained who had made the correction? In terms of meaning, the word "Sida-Sida" refers to a court official who had been emasculated or castrated. Perhaps a mistake had occurred when Raja Haji Yahya romanized the original manuscript which was written in Jawi, thus he made a correction and overwrote the word Sida-Sida with "Sayid-Sayid". As such, in this book, the writer will use the title Salasilah Raja Perak Berhubungan dengan Sayid-Sayid Chandaryang, in accordance with the genealogy of the sayyids, many of whom have lived in Chenderiang for a long time.

11. Pelesit, in the Malay world of black magic, refers to a so-called inherited spirit which serves a female master who rears it for protection, power to harm others, beauty, monetary gains, etc. Pelesit are believed to be able to transform itself into a grasshopper. Some pelesit keepers are said to isolate themselves from society and keep very much to themselves.

12. Pekasam is a traditional food eaten with rice, prepared by preserving fish (usually fresh-water fish such as sepat, haruan, lampam jawa, tilapia) in salt (or tamarind) for several weeks or months and then later marinating the fish with fried ground rice for several weeks.

13. Tempoyak is fermented durian that has a sour, salty and sometimes nutty flavour. It is eaten with rice or added to main dishes which is also eaten with rice.

14. In accordance with the tradition of oral tale narration in former times, before a tale is presented, the narrator would perform the ritual "Buka Panggung" (opening ritual) which involved the medicine man or shaman reading incantations invoking spirits or the souls of dead gurus and ancestors. It was mandatory for the narrator to perform this ritual as a show of respect towards his gurus and ancestors. Following the ritual, 
the narrator would appeal to these spirits and ancestors to ensure that the presentation of the tale proceed without any untoward interruption.

15. R.O. Winstedt (1969: 127-31) also lists the names of a number of well-known medicine men in Gopeng during Pawang Ana's life time, whom he referred to as "famous local medicine-man". Amongst them are Pawang Talib and his guru, Pawang Teh. Besides this, the name, Pawang Busu, is also mentioned. This shows that there existed in Gopeng at that time, several prominent medicine men, and it was the practice among these healers not to use their full name.

16. This statement is still hypothetical as until today the original version of the folk tales narrated by Pawang Ana to R.O. Winstedt have still not been found, be it in the form audio recordings (if they exist at all), or in the form of transcripts of the original recordings.

\section{REFERENCES}

Abdur-Razzaq Lubis and Khoo Salma Nasution, "Raja Bilah and the Mandailings in Perak: 1875-1911" in MBRAS Monograph No. 35, 2003.

Ahmad Fauzi Mohd. Basri (ed.), 1992. Misa Melayu. Kuala Lumpur: Dewan Bahasa dan Pustaka.

Andaya, Barbara Watson, 1979. Perak, The Abode of Grace. Kuala Lumpur: Oxford University Press.

"A Shaer by the late Raja Haji Yahya bin Raja Muhammad Ali" in JMBRAS (12). Part II, pp. 169-70, 1934.

Ayob Hashim, Dato', nd. Adat-Istiadat Diraja Negeri Perak Darul Ridzuan. Secretary of the Dewan Negara Perak Darul Ridzuan.

Buyong Adil, 1972. Sejarah Perak. Kuala Lumpur: Dewan Bahasa dan Pustaka. Cerita Jenaka oleh Raja Haji Yahya, 1963. Kuala Lumpur: Penerbit Fajar Bakti.

Fawzi Basri, M.A., 1986. Cempaka Sari: Sejarah Kesultanan Negeri Perak. Ipoh: Yayasan Perak.

Jamilah Hani Esa, 2010. Teks dan Konteks: Budaya Masyarakat Desa dalam Ceritacerita Lisan Negeri Perak. MA Dissertation, Pusat Pengajian Ilmu Kemanusiaan, Universiti Sains Malaysia, Penang (to be published).

Jelani Harun, 2011. Umpama Sebuah Bahtera: Kajian Naskhah Melayu Sejarah Kesultanan Negeri Perak. Kuala Lumpur: Arkib Negara Malaysia.

Laidlaw, G. M., "The Story of Kherudin” (pp. 27-57), "Pa' Senik and his son-in-law Awang” (pp. 59-64) and "The Baboon Pa' Si Bagok and the Girl” (pp. 65-71) in JSBRAS (45), 1906.

Maxwell, W.E., "Notes on Two Perak Manuscripts" in $J S B R A S(2)$, pp. 183-83, 1878.

Maxwell, W.E., "The History of Perak from Native Sources" in JSBRAS (9), pp. 305-21, 1884.

Maxwell, W.E., "Raja Donan, a Malay Fairy Tale Told by a Rhapsodist" in JSBRAS 
(18), pp. 241-69, 1886.

McNair, J.F.A., 1972. Perak and The Malays. Kuala Lumpur: Oxford University Press.

Mohd. Taib Osman, 1989. Malay Folk Beliefs. Kuala Lumpur: Dewan Bahasa dan Pustaka.

Muhammad Haji Salleh, 2010. Puitika Sastera Melayu. Kuala Lumpur: Dewan Bahasa dan Pustaka.

Panduan Koleksi Surat-Surat Persendirian Arkib Negara Malaysia, 1988. Kuala Lumpur: Arkib Negara Malaysia.

Pantang Larang dan Petua Orang Tua, 2005. Ipoh: Jabatan Kebudayaan, Kesenian dan Warisan Negeri Perak.

Pawang Ana and Raja Haji Yahya, 1960. Hikayat Awang Sulung Merah Muda (From the manuscript by R.O. Winstedt and A.J. Sturrock). Shah Alam: Penerbit Fajar Bakti.

Pawang Ana and Raja Haji Yahya, 1971. Hikayat Malim Dewa (From the manuscript by R.O. Winstedt and A.J. Sturrock). Shah Alam: Penerbit Fajar Bakti.

Pawang Ana and Raja Haji Yahya, 1985. Hikayat Anggun Che Tunggal (From the manuscript by R.O. Winstedt and A.J. Sturrock) . Shah Alam: Penerbit Fajar Bakti.

Pawang Ana and Raja Haji Yahya, 1999. Hikayat Raja Muda (From the manuscript by R.O. Winstedt and A.J. Sturrock). Shah Alam: Penerbit Fajar Bakti.

Winstedt, R.O., "Father Civet" in JSBRAS (50), pp. 95-90, 1908.

Winstedt, R.O., 1909. Papers on Malay Subjects: Life and Customs. Part II. Kuala Lumpur: FMS Government Press.

Winstedt, R.O., 1916. Malayan Memories (with Illustrations by Dorothea A. H. Aldworth). Singapore: Kelly and Walsh Limited.

Winstedt, R.O., 1917. "The Hadramaut Saiyids of Perak and Siak” in JSBRAS (79), pp. 49, 1917.

Winstedt, R.O. and Wilkinson, R.J., "A History of Perak" dlm. JMBRAS (12). Part I and Part II, 1934.

Winstedt, R.O., 1969. Start From Alif: Count From One: An Autobiographical Memoire. Kuala Lumpur: Oxford University Press.

Winstedt, R.O., 1982. The Malay Magician being Shaman, Saiva and Sufi. Kuala Lumpur: Oxford University Press.

Zabidin Ismail, 2010. "Biografi dan Sumbangan Pawang Ana dalam Kesusasteraan Melayu Tradisional", Working paper Seminar Pemikiran Pawang Ana, 25 October 2010, Auditorium Jabatan Kebudayaan dan Kesenian Negara, Ipoh, organized by Persatuan Karyawan Perak. 


\section{BRIEF BIODATA OF RAJA HAJI YAHYA}

\begin{tabular}{|c|c|}
\hline Name & $\begin{array}{l}\text { Raja Haji Yahya bin Raja Syed Muhammad Ali bin } \\
\text { Raja Alang Syed Hussain }\end{array}$ \\
\hline Lifespan & $\begin{array}{l}\text { Born around the middle of the 19th century and died } \\
\text { in the early 1930s. It can only be surmised that he was } \\
\text { born in Chenderiang and died in Kuala Dipang, Perak. }\end{array}$ \\
\hline Origin & $\begin{array}{l}\text { A descendent of Sultan Iskandar Dzulkarnain Shah } \\
\text { (1754-1764) and Sayid Hussein al-Faradz from Hadra- } \\
\text { maut. Was also related to Syed Ahmad bin Syed Aqil } \\
\text { bin Syed Yassin al-Faqih al-Yahya from Terengganu. }\end{array}$ \\
\hline Place of Residence & $\begin{array}{l}\text { Chenderiang and several other districts in the state of } \\
\text { Perak (Temoh, Kuala Kurau, Kota Setia, Kuala Dipang) }\end{array}$ \\
\hline Occupation & $\begin{array}{l}\text { Headman in the state of Perak. Was also a reputable } \\
\text { medicine man. }\end{array}$ \\
\hline Siblings & $\begin{array}{l}\text { Syed Alwi, Syed Osman, Syed Mansur, and Sharifah } \\
\text { Arfah. Syed Alwi, Syed Othman and Syed Mansur } \\
\text { were, at different times, appointed headman of Mukim } \\
\text { Teja, in the District of Kampar, Perak. }\end{array}$ \\
\hline Wife and children & $\begin{array}{l}\text { Was married to Raja Long Aishah binti Raja Hassan } \\
\text { (the daughter of Raja Bendahara Alang Iskandar Shah, } \\
\text { Perak). Had five children: Raja Kamaral Bahrain, Raja } \\
\text { Sharifah Salamiah, Raja Sharifah Hamidah, Raja Syed } \\
\text { Chik Abdul Majid and Raja Sharifah Hitam Hafifah }\end{array}$ \\
\hline Pilgrimage to Mecca & $\begin{array}{l}\text { No record of this, but it is estimated to be some time } \\
\text { in the early } 1900 \text { s. }\end{array}$ \\
\hline Writing ability & $\begin{array}{l}\text { Writer and modifier of folk tales narrated by Pawang } \\
\text { Ana. Also wrote the history and genealogy of the rulers } \\
\text { of Perak and a number of poems, mantras and Malay } \\
\text { syairs. Well-known as a collector and writer of Malay } \\
\text { comic tales from Perak. }\end{array}$ \\
\hline Contribution & $\begin{array}{l}\text { Of great help to R.O. Winstedt in compiling, writing } \\
\text { and rewriting the oral literature of the state of Perak, } \\
\text { including matters relating to the genealogy of the Perak } \\
\text { rulers, rituals and customary practices, the traditional } \\
\text { practices of the medicine man, mantras, wedding cer- } \\
\text { emonies, construction of houses, dress code, food, } \\
\text { social etiquette and others. }\end{array}$ \\
\hline
\end{tabular}


JELANI HARUN

\begin{tabular}{|l|l|}
\hline Son-in-law & $\begin{array}{l}\text { One of his sons-in-law, Mir Hassan from Kampar, Perak, } \\
\text { wrote Seri Rama, Raja Donan and Raja Ambong in } \\
\text { 1886. Perhaps inspired by Raja Haji Yahya. }\end{array}$ \\
\hline Legacy of authorship & $\begin{array}{l}\text { Raja Kamaral Bahrain (1901-1965) was born in } \\
\text { Chenderiang and had married Raja Yong Arba'ayah } \\
\text { from the Perak royal family. They were blessed with } \\
\text { five children, Raja Shahruzzaman, Raja Shahrizan, } \\
\text { Raja Haji Shahrustan, Raja Mariam and Raja Shahrin } \\
\text { Nahrin. Of the five grandchildren of Raja Haji Yahya, } \\
\text { only Raja Shahrustan, who is now 90 years old, was } \\
\text { still alive in 2014. }\end{array}$ \\
\hline Commendation & Was nicknamed "Pot Lorrit" by R.O. Winstedt (1969). \\
\hline
\end{tabular}

(Translated by Nor Azizah Abu Bakar) 